\title{
Dinamika Keterlibatan Masyarakat dalam Pengembangan Fasilitas di Objek Wisata Pantai Cemara Sewu
}

\author{
Fitria Nurmalita Sari \\ Program Studi Pariwisata, Fakultas Ilmu Budaya, Universitas Gadjah Mada \\ Email: fitria.nurmalita.s@mail.ugm.ac.id
}

\begin{abstract}
This study aims at describing the involvement of the local community in developing facilities in Cemara Sewu Beach. Based on observations and interviews, it was found that the local community of Grogol VII were actively involved in providing facilities by contributing ideas, energy, and even materials such as money. Through the provision of these facilities, the community can obtain economic benefits, such as new jobs and business opportunities that can give them additional income.
\end{abstract}

Keyword: community involvement, tourism facilities, Cemara Sewu beach

\section{Pendahuluan}

Bantul merupakan salah satu kabupaten di DIY yang berbatasan langsung dengan Samudra Hindia sehingga membuat wilayah ini memiliki potensi yang sangat besar dalam hal pengembangan objek wisata pantai. Sampai saat ini telah banyak pantai di Kabupaten Bantul yang dibuka untuk umum bagi wisatawan seperti Pantai Parangtritis, Pantai Depok, dan Pantai Goa Cemara. Banyak pula bermunculan pantai baru yang dikelola secara swadaya oleh masyarakat sekitar salah satunya yaitu Pantai Cemara Sewu. Secara administratif Pantai Cemara Sewu berada di Desa Parangtritis, Kecamatan Kretek, Kabupaten Bantul. Letaknya kurang lebih $2 \mathrm{~km}$ arah barat dari Pantai Parangtritis. Pantai ini terbilang masih baru karena baru mulai dibuka sebagai objek wisata oleh masyarakat Dusun Grogol VII pada bulan Februari tahun 2016.

Sebagai salah satu objek wisata pantai baru di Kabupaten Bantul, Pantai Cemara Sewu memiliki sejarah yang menarik. Pada awalnya Pantai Cemara Sewu merupakan lahan gundul berpasir yang gersang. Oleh pemerintah lahan tersebut kemudian ditanami pohon cemara udang supaya dapat mengurangi kecepatan angin sehingga area persawahan warga dapat terlindungi. Penghijauan tersebut selain merubah kondisi kawasan yang semula gersang menjadi rindang dan sejuk juga menjadi berkah bagi masyarakat Dusun Grogol VII untuk dimanfaatkan sebagai objek wisata. Potensi alam berupa deretan pohon cemara udang tersebut ditangkap oleh masyarakat sebagai peluang untuk mengembangkan pariwisata dengan membuka destinasi wisata baru bernama Pantai Cemara Sewu. ${ }^{1}$ Untuk mengembangkan wisata di hutan cemara udang, masyarakat sepakat untuk mengawalinya dengan membangun fasilitas wisata. Fasilitas wisata yang dibangun berupa tempat parkir, kamar mandi, warung makan, mushola, dan aula.

Butler (1980) dalam Pitana (2005:103) menggambarkan bahwa destinasi wisata berkembang seiring berjalannya waktu dan mengikuti siklus dari tidak adanya aktivitas wisata sama sekali sampai dengan pembangunan masif dan selanjutnya terjadi kejenuhan dan penurunan. Konsep ini dikenal dengan istilah Tourist Area Lifecycle (TALC) yang meliputi tujuh fase dimulai dari 1) eksplorasi, 2) keterlibatan, 3) pembangunan, 4) konsolidasi, 5) stagnasi, 6) penurunan, dan 7) peremajaan. Pantai Cemara Sewu apabila dilihat 
menggunakan konsep yang dikembangkan oleh Butler, maka berada pada fase kedua yaitu keterlibatan. Keterlibatan diartikan oleh Butler (1980) dalam Pitana (2005:103) sebagai fase di mana jumlah kunjungan di suatu daerah wisata mulai meningkat sehingga sebagian masyarakat lokal mulai menyediakan berbagai fasilitas yang memang diperuntukan bagi wisatawan. Kontak antara wisatawan dengan masyarakat lokal mulai tinggi, dan masyarakat sudah mulai mengubah polapola sosial yang ada untuk merespon perubahan ekonomi yang terjadi. Kondisi di lapangan menunjukkan bahwa potensi hutan cemara udang mampu menstimulasi masyarakat untuk melakukan pengembangan wisata. Pengembangan wisata yang dilakukan oleh masyarakat yaitu dimulai dari penyediaan fasilitas wisata. Pantai Cemara Sewu belum memasuki fase pembangunan karena hingga kini masyarakat masih mandiri mengembangkan fasilitas wisata, sedangkan ciri-ciri dari fase pembangunan berdasarkan TALC yaitu investasi dari luar mulai masuk, serta mulai munculnya pasar pariwisata secara sistematis. Fasilitas lokal mulai tersisihkan digantikan oleh fasilitas yang benar-benar turistik dengan standar internasional. Ciri-ciri tersebut belum nampak di Pantai Cemara Sewu karena hingga kini masyarakat masih mandiri menyediakan fasilitas wisata.

Dalam prosesnya penyediaan fasilitas wisata yang dilakukan oleh masyarakat tersebut sering mengalami berbagai kendala akibat adanya perbedaan pandangan di antara anggota pokja yang terkadang menjadi gejolak di dalam proses pengembangan fasilitas di Pantai Cemara Sewu. Oleh karena itu, penelitian ini bertujuan untuk melihat dinamika keterlibatan masyarakat Dusun Grogol VII dalam pengembangan fasilitas di Pantai Cemara Sewu.

\section{Kerangka Teori}

Diakui bahwa sumbangan sektor pariwisata terhadap perolehan devisa dan penciptaan lapangan kerja secara makro cukup signifikan. Laporan berbagai kajian ahli menyimpulkan bahwa sumbangan pariwisata yang secara siginifikan pada perkembangan ekonomi suatu negara atau daerah tampak dalam bentuk perluasan kerja, peningkatan pendapatan devisa, dan pemerataan pembangunan spasial (Damanik, 2013:4). Sejumlah penelitian juga telah dilakukan terhadap dampak ekonomi dari pariwisata dan hasilnya sudah dapat diduga yakni pariwisata memberikan dampak positif terhadap ekonomi masyarakat, baik pada tingkat lokal ataupun regional dan nasional (AhimsaPutra, 2011). Namun hendaknya disadari bahwa data makro ekonomi pariwisata tersebut tidak banyak berbicara tentang apakah atau bagaimana pemerintah akan memanfaatkan devisa itu untuk mengembangkan program-program kesejahteraan masyarakat atau lebih praktisnya mengentaskan kehidupan penduduk miskin. Besaran devisa yang diraih dari pariwisata hanya mampu berbicara tentang potensinya bagi peningkatan pendapatan, sedangkan mekanisme distribusinya tetap merupakan sebuah misteri (Damanik, 2013:5). Hal yang sama juga turut diungkapkan oleh AhimsaPutra (2011), yang menjelaskan bahwa kajiankajian ekonomi pariwisata yang bersifat makro sebagian besar lebih ditujukan untuk menampilkan dampak ekonomi yang bersifat umum sedangkan gambaran mengenai perilaku ekonomi yang nyata dari warga masyarakat ketika dihadapkan dengan pariwisata justru tidak begitu tampak.

Hudayana (2018: 29) menjelaskan bahwa kajian-kajian ekonomi yang bersifat makro memang lebih bisa dipercaya karena ukurannya bersifat material dan matematik, sehingga dianggap lebih relevan dan dapat dipertanggung jawabkan. Hal tersebutlah yang membuat sebagian besar penelitian ditujukan untuk memperoleh data ekonomi yang bersifat kuantitatif. Namun menurut Hudayana (2018: 29) pendekatan kuantitatif tersebut justru mengabaikan peranan pelaku dan hanya berfokus pada hasil tindakan bukan pikiran maupun perkataan pelaku. Oleh sebab itu, penting kiranya memberi perhatian pada perilaku masyarakat di bidang pariwisata bukan lagi terpaku pada deretan angka-angka statistik yang membius dan sering kali tidak relevan dengan apa yang sesungguhnya terjadi di masyarakat. Gambaran semacam ini sangat diperlukan dan juga tidak kalah pentingnya dengan gambaran kuantitatif yang bersifat makro, karena dari sini dapat diperoleh informasi yang lebih rinci mengenai suatu gejala yang terjadi di masyarakat lengkap dengan berbagai masalah dan cara mereka menyelesaikan masalah tersebut (Ahimsa-Putra, 2011). 
Menurut Ahimsa-putra (2011), basis pendekatan atau konsep yang sesuai untuk menampilkan pola-pola perilaku warga masyarakat secara nyata dalam bidang ekonomi adalah dengan menggunakan pendekatan yang berorientasi pada pelaku (actor oriented), dalam arti bahwa masyarakat yang berada di daerah wisata akan dipandang sebagai "pelaku" dengan penekanannya pada aktivitas ekonomi yang dijalankan oleh masyarakat. Paradigma seperti ini merupakan salah satu paradigma yang telah berkembang dalam ilmu ekonomi dan atropologi, terutama antropologi ekonomi, antropologi politik, dan antropologi ekologi (Ahimsa-Putra, 2011). Dalam pendekatan yang berorientasi pada pelaku, manusia diasumsikan pertama, memiliki kesadaran dan pengetahuan mengenai berbagai hal yang ada di sekelilingnya. Hal-hal ini dipandang sebagai sejumlah "possible alternative modes of behavior" atau sebagai kemungkinan-kemungkinan untuk berperilaku, yang jika diikuti akan memberikan hasil-hasil tertentu. Kemudian yang kedua manusia diasumsikan memiliki berbagai alternatif, namun ia akan memilih alternatif yang dipandang akan memberikan hasil paling tinggi dan paling maksimal. Mereka juga akan berusaha mencari informasi-informasi yang relevan, memprosesnya informasi-informasi tersebut, menilai hasilnya dan kemudian baru mengambil suatu keputusan (Long, 1977 dalam Ahimsa-Putra, 2003).

Atas dasar berbagai asumsi di atas, dapat disimpulkan bahwa dengan menggunakan pendekatan actor oriented seorang peneliti jadi dapat memusatkan perhatiannya pada pelaku dan perilaku ekonomi warga masyarakat di sebuah daerah wisata. Hal semacam ini tidak ditemukan dalam penelitian ekonomi yang memusatkan perhatian pada "dampak ekonomi”, karena konsep "dampak ekonomi" diartikan sebagai gejala-gejala ekonomi yang muncul dalam suatu masyarakat sebagai akibat dari adanya gejala yang baru di situ. Jadi, hubungan di antara gejala-gejala di situ adalah hubungan sebab-akibat. Gejala-gejala ekonomi tersebut merupakan agregat (kumpulan) dari gejala-gejala ekonomi yang lebih kecil, yang berupa perilaku-perilaku ekonomi dan aktivitas ekonomi. Sebagai agregat, gejala-gejala ekonomi tersebut akan tampil dalam wujud angka-angka statistik yang seringkali memperlihatkan keterulangan atau keteraturan tertentu. Oleh karena itu, konsep dampak ekonomi pada dasarnya merupakan konsep yang lebih cocok untuk studi di tingkat makro, sedang untuk penelitian di tingkat mikro yang bertujuan untuk mengungkapkan perilaku ekonomi yang nyata, dengan pendekatan actor oriented akan lebih sesuai (Ahimsa-Putra, 2011).

Keterlibatan masyarakat merupakan kata kunci untuk mempercepat pencapaian kesejahteraan melalui pengembangan pariwisata (Damanik, 2013:9). Masyarakat memegang peran kunci dalam pengembangan pariwisata karena masyarakatlah yang memahami kondisi wilayahnya dan mengerti kebutuhan yang diperlukan oleh wisatawan (Godfrey \& Clarke, 2000 dalam Aref, 2010). Pelibatan ini membuat masyarakat kemudian merasa memiliki dan bertanggung jawab terhadap proses keberlanjutan program pembangunan (Raharjana, 2012). Beberapa bentuk keterlibatan masyarakat dalam pengembangan pariwisata tersebut bisa melalui penyediaan akomodasi, penyediaan kubutuhan konsumsi, informasi, transportasi, fasilitas serta pelayanan untuk pengembangan pariwisata (Godfrey \& Clarke, 2000 dalam Aref, 2010).

Pengembangan pariwisata yang melibatkan masyarakat tercermin pada pola pengembangan di Pantai Cemara Sewu. Masyarakat Dusun Grogol VII menjadi penggerak pengembangan wisata dengan memanfaatkan potensi alam berupa hutan cemara untuk dijadikan objek wisata. Setelah masyarakat melakukan identifikasi, diketahui bahwa untuk mengembangkan wisata maka diperlukan pembangunan fasilitas wisata sehingga aktivitas pertama yang mereka lakukan di dalam pengembangan wisata di Pantai Cemara Sewu ialah membangun fasilitas wisata. Menurut Spillane (1994:67) fasilitas wisata merupakan sarana dan prasarana yang dibutuhkan untuk melayani pengunjung selama di destinasi wisata. Fasilitas pertama yang dibangun oleh masyarakat di Pantai Cemara Sewu ialah tempat parkir dan kamar mandi karena menurut mereka kedua fasilitas tersebut adalah yang utama dan harus ada di tempat wisata. Sementara fasilitas lainnya seperti warung makan, musala, dan aula sifatnya sebagai pendukung yang dibangun sesuai dengan kebutuhan pengunjung di Pantai Cemara Sewu. Hal tersebut sesuai dengan yang diungkapkan oleh Spillane (1994:67) bahwa 
fasilitas cenderung berorientasi pada atraksi di suatu lokasi karena fasilitas harus terletak dekat dengan pasarnya. Fasilitas cenderung mendukung bukan mendorong pertumbuhan dan berkembang pada saat yang sama atau sesudah atraksi berkembang.

Pada penelitian ini akan berfokus pada keterlibatan masyarakat dalam penyediaan fasilitas karena hal tersebut merupakan aktivitas pertama yang dilakukan oleh masyarakat dalam mengembangkan wisata di Pantai Cemara Sewu.

\section{Metodologi Penelitian}

Metode pendekatan yang digunakan dalam penelitian ini adalah deskriptif dengan tujuan menggambarkan kondisi dan fenomena yang diperoleh di lapangan kemudian dianalisis dalam bentuk kalimat sehingga dapat diperoleh suatu kesimpulan mengenai dinamika keterlibatan masyarakat dalam pengembangan fasilitas di objek wisata Pantai Cemara Sewu. Pengumpulan data diperolah melalui wawancara dan observasi. Penelitian ini mengambil beberapa informan yaitu Bapak Sudarman selaku penggagas berdirinya Pantai Cemara Sewu, Bapak Sugiran, dan Mas Yana selaku pengurus Pantai Cemara Sewu, serta Mbak Yuli dan Bapak Slamet yang merupakan anggota kelompok Pantai Cemara Sewu. Selanjutnya setelah data terkumpul kemudian dilakukan analisis meliputi reduksi data, penyajian data, dan penarikan kesimpulan. Dalam menganalisis data tahapan pertama yang dilakukan yaitu reduksi data dengan cara merangkum hasil wawancara dan observasi yang diperoleh di lapangan yang selanjutnya dipilih sesuai dengan fokus penelitian. Tahapan yang kedua adalah penyajian data dalam bentuk narasi deskriptif terkait proses yang dilalui oleh masyarakat dalam membangun fasilitas wisata dan keuntungan yang diperoleh masyarakat dari penyediaan fasilitas. Setelah melalui tahapan reduksi dan penyajian, maka dapat ditarik kesimpulan mengenai dinamika keterlibatan masyarakat dalam pengembangan fasilitas di objek Pantai Cemara Sewu.

\section{Hasil dan Pembahasan}

4.1 Keterlibatan Masyarakat Dusun Grogol VII Dalam Penyediaan Fasilitas Wisata di Pantai Cemara Sewu

Keterlibatan masyarakat dalam pengembangan destinasi pariwisata menjadi hal yang penting karena masyarakatlah yang lebih mengetahui dan memahami akan potensi wilayahnya serta mengerti kebutuhan yang diperlukan oleh wisatawan (Raharjana, 2012). Sebagaimana yang terjadi dalam pengembangan wisata di Pantai Cemara Sewu. Berawal dari gagasan masyarakat Dusun Grogol VII yang melihat bahwa kehadiran hutan cemara di pinggir pantai merupakan potensi pariwisata yang menarik sehingga terdorong untuk membuka destinasi wisata baru dengan memanfatakan potensi alam tersebut. Untuk mengembangkan hutan cemara menjadi tempat wisata masyarakat terlebih dahulu melakukan identifikasi dan diketahui bahwa untuk mengembangkan wisata diperlukan pembangunan fasilitas wisata sehingga aktivitas pertama yang mereka lakukan di dalam pengembangan wisata di Pantai Cemara Sewu ialah membangun fasilitas wisata.

\subsubsection{Tempat Parkir}

Ide pengembangan pariwisata pertama kali dicetuskan oleh salah seorang warga dusun Grogol VII bernama Sudarman pada tahun 2015. Ide tersebut kemudian ia sampaikan kepada dua rekannya yaitu Sugiran dan Iwan, namun belum dapat terlaksana karena pada waktu itu mereka masih memiliki kesibukan lain. Setelah tertunda selama setahun, pada tahun 2016 mereka akhirnya membulatkan tekad untuk merealisasikan ide pengembangan wisata. Sudarman dibantu dua anaknya dan dua rekannya kemudian menyebarluaskan ide tersebut kepada warga Dusun Grogol VII lainnya seraya mengajak mereka untuk ikut terlibat dalam pembangunan. Respon yang mereka peroleh saat mengajak warga Dusun Grogol VII untuk ikut terlibat dalam pembangunan pun beragam. Ada yang meragukan dengan anggapan bahwa ide tersebut terlalu muluk dan mustahil untuk direalisasikan, namun ada pula warga yang menyambut positif. Ada 13 orang warga Dusun Grogol VII yang mendukung ide Sudarman dan siap membantu sehingga total jumlah warga yang terlibat di awal pembangunan Pantai Cemara Sewu ada 18 orang. Delapan belas orang inilah yang kemudian menjadi perintis pembangunan wisata di Pantai Cemara Sewu. Sebagai wujud keseriusan mereka melakukan pengembangan wisata, 18 orang yang telah berkumpul tersebut kemudian membentuk 
sebuah kelompok yaitu Kelompok Kerja (Pokja) Pantai Cemara Sewu.

Fasilitas pertama yang dibangun oleh pokja ialah tempat parkir. Pembangunan tempat parkir dijadikan sebagai rencana awal oleh pokja dalam pengembangan wisata Pantai Cemara Sewu dengan alasan untuk untuk menghindari potensi konflik sebab hutan cemara udang ini berada persis di pinggir jalan raya penghubung antara Pantai Parangkusumo dengan Pantai Depok. Jika tidak disediakan kantong parkir sendiri maka pengunjung yang datang akan secara langsung memakirkan kendaraanya di pinggir jalan dan jelas hal tersebut dapat menggangu lalu lintas. Pembangunan tempat parkir tersebut dilaksanakan pada tanggal 10 Januari 2016 dimulai dari menentukan letak lokasi yang akan dipergunakan sebagai lahan parkir. Berdasarkan kesepakatan bersama untuk tempat parkir akan diletakkan di dalam area hutan cemara udang dengan memanfaatkan lahan kosong seluas $4 \times 9 \mathrm{~m}$, sedangkan untuk parkir mobil berada berseberangan dengan tempat parkir motor dengan memanfaatkan sela antara pohon cemara.

Setelah menentukan lokasi parkir, pokja kemudian melakukan iuran sebesar Rp50.000,00 per orang sehingga terkumpul dana sebesar Rp900.000,00. Dana tersebut kemudian dipergunakan untuk membeli asbes yang akan dipakai untuk menutupi area parkir motor. Proses pembangunan tempat parkir motor tersebut dikerjakan oleh pokja secara gotong royong selama kurang lebih 1 minggu. Pada saat yang bersamaan pokja juga membangun gapura sederhana dari bambu bertuliskan "Objek wisata Pantai Cemara Sewu". Dibangunnya gapura tersebut bertujuan supaya Pantai Cemara Sewu diketahui oleh wisatawan terutama mereka yang sedang berkunjung ke kawasan Pantai Parangtritis. Pada tanggal 22 Februari tahun 2016 Pantai Cemara Sewu resmi dibuka oleh pokja sebagai objek wisata pantai.

Tempat parkir tersebut kemudian dikelola oleh pokja dengan cara menyediakan jasa parkir. Awalnya biaya parkir yang ditetapkan yaitu sebesar Rp3.000,00 untuk motor, Rp5.000,00 untuk mobil, sementara bus sebesar Rp20.000,000. Pada pertengahan tahun 2018 Dinas Perhubungan (Dishub) Kabupaten Bantul melakukan sosialiasi terkait penyesuaian tarif parkir di kawasan wisata sepanjang Pantai Parangkusumo hingga Pantai Depok. Sesuai dengan peraturan Perbup no.77 tahun 2017 tarif parkir kendaraan di kawasan wisata dibedakan menjadi 5 jenis yaitu untuk sepeda sebesar Rp1.000,00, sepeda motor Rp3.000,00, kendaraan bermotor roda $4 \mathrm{Rp} 5.000,00$, kendaraan roda $6 \mathrm{Rp} 10.000,00$ serta kendaraan dengan roda lebih dari 6 sebesar Rp15.000,00. Dengan adanya peraturan tarif parkir tersebut tarif parkir di Pantai Cemara Sewu juga turut berubah mengikuti peraturan yang telah ditetapkan oleh Dishub.

Pada awal pengembangan, pokja sepakat bahwa pendapatan yang diperoleh dari parkir seluruhnya akan dikumpulkan untuk membiayai pengembangan fasilitas wisata lainnya. Setelah berhasil mengumpulkan selama 3 bulan, pokja baru mulai menetapkan tentang pembagian pendapatan agar kedepannya pengembangan fasilitas di Pantai Cemara Sewu dapat terus berjalan dan di sisi lain masyarakat juga bisa merasakan keuntungan dari pengembangan fasilitas tersebut. Berdasarkan hasil kesepakatan maka dibuatlah aturan yaitu hasil dari seluruh pendapatan akan dibagi berdasarkan persentase yaitu sebesar $40 \%$ akan disisihkan untuk mengisi kas kelompok sedang sisanya sebesar $60 \%$ akan dibagikan kepada yang bekerja. Cara pembagian pendapatan untuk yang bekerja pun telah dibuat yaitu berdasarkan jam kerja. Untuk jam kerja bagi setiap anggota dimulai dari jam 08.00 WIB sampai dengan jam 18.00 WIB. Perhitungannya sebagai berikut misalkan pada hari Minggu total pendapatan parkir mendapatkan $\mathrm{Rp} 2.000 .000,00$ maka berdasarkan kesepakatan bahwa sebesar $40 \%$ yaitu Rp800.000,00 akan disisihkan untuk masuk kas, sedangkan sisanya 60\% yaitu Rp1.200.000,00 dibagikan ke anggota yang bekerja pada hari itu sesuai dengan jam kerjanya.

Berjalan 1 tahun, pokja mengembangkan tempat parkir dengan cara memindahkan area parkir yang berada di dalam area hutan menjadi di luar agar lebih mudah dijangkau oleh semua kendaraan. Alasan lain yang mendorong pokja untuk mengembangkan tempat parkir yaitu karena belum memiliki tempat parkir khusus untuk bus. Untuk tempat parkir yang baru ini, pokja membangunnya di lahan seluas 50x50 m yang kurang lebih dapat menampung 30 mobil, 50 motor, dan 10 bus dalam sehari. Dalam kurun waktu 1 tahun semenjak tempat parkir menempati lokasi baru pokja sudah 
melakukan perluasan hingga 2 kali dan kini luas tempat parkir di Pantai Cemara Sewu mencapai sekitar 50x100 m (periksa gambar 1).

\section{Gambar 1. Tempat Parkir}

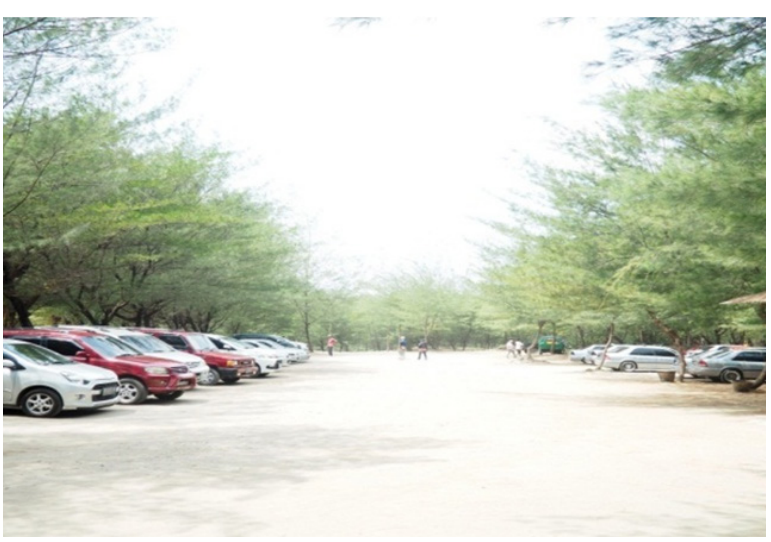

(Sumber: Sari, 2017)

Pencapaian yang diraih oleh pokja karena dapat mengembangkan tempat parkir ini rupanya menarik minat masyarakat Dusun Grogol VII lainnya untuk bergabung dengan pokja. Dari yang semula hanya ada 18 orang kemudian di tahun 2017 bertambah menjadi 71 orang. Dari 71 anggota yang tergabung ada sebanyak 54 orang yang memilih untuk terlibat sebagai petugas parkir dan seluruhnya adalah kaum laki-laki. Bertambahnya anggota yang ingin menjadi petugas parkir ini kemudian disikapi oleh pengurus dengan membuatkan jadwal piket parkir. Pengurus pokja membagi 54 orang tersebut ke dalam 3 kelompok piket. Tiga kelompok piket tersebut bekerja secara bergiliran menurut jadwal yang telah dibuat oleh pengurus. Khusus untuk hari Minggu atau hari libur lainnya semua kelompok parkir diperbolehkan untuk masuk bekerja mengingat kondisi Pantai Cemara Sewu ketika hari libur ramai pengunjung sehingga dari segi pendapatan parkir pun juga meningkat bila dibandingkan dengan hari-hari biasa (Senin-Sabtu).

\subsubsection{Kamar Mandi}

Fasilitas selanjutnya yang dibangun oleh pokja ialah kamar mandi. Selain tempat parkir, kamar mandi ini juga dianggap oleh pokja sebagai fasilitas penting yang harus ada di tempat wisata sehingga pembangunan kamar mandi ini menjadi rencana kedua yang akan dilakukan oleh pokja setelah membangun tempat parkir. Biaya untuk membangun kamar mandi dilakukan swadaya oleh pokja dengan melakukan iuran sebesar Rp100.000,00 per orang sehingga terkumpul dana sebesar Rp1.800.000,00. Keterbatasan modal yang dimiliki pada waktu itu membuat pokja hanya dapat membangun 3 unit kamar mandi. Tiga unit kamar mandi yang dibangun pada waktu itu belum dilengkapi dengan WC sehingga kamar mandi hanya dapat digunakan oleh pengunjung untuk bilas. Kamar mandi tersebut kemudian penggunaanya dikenai tarif sebesar Rp4.000,00 untuk mandi dan Rp2.000,00 untuk buang air kecil.

Pada awal pembangunan kamar mandi, terjadi gejolak yang bermula dari tawaran salah satu anggota pokja berupa meteran listrik yang tidak terpakai di rumahnya untuk dibeli dengan sistem pembayaran angsuran sesuai kemampuan pokja. Pada waktu itu pengurus pokja tidak merasa terbebani dengan adanya cicilan yang harus mereka bayarkan setiap bulannya karena si pemilik meteran listrik tidak mematok sejumlah biaya. Namun seiring berjalannya waktu anggota yang menawarkan tadi justru meminta untuk segera dilunasi dengan biaya sebesar Rp5.000.000,00. Kondisi tersebut jelas membuat pokja kebingungan sebab pada saat itu Pantai Cemara Sewu baru mulai berkembang dan dana kas yang terkumpul pun masih sedikit. Setelah dimusyawarahkan akhirnya disepakati bahwa meteran listrik tersebut akan dilunasi dengan dicicil sebesar Rp1.000.000,00 per bulan. Kesepakatan tersebut menguntungkan kedua belah pihak karena disatu sisi pengurus jadi memiliki waktu untuk mempersiapkan dananya terlebih dahulu dan anggota baru tersebut juga terpenuhi haknya.

Berjalan 6 bulan semenjak diresmikan, situasi yang sering terlihat di Pantai Cemara Sewu saat hari Minggu ialah antrian panjang di depan kamar mandi mengingat jumlah kamar mandi yang tersedia hanya ada 3 unit. Melihat kondisi tersebut, pokja akhirnya memutuskan untuk menambah 3 unit kamar mandi lagi dengan fasilitas yang lebih lengkap dari sebelumnya yaitu WC duduk. Selanjutnya tanggal 22 April tahun 2017, Pantai Cemara Sewu mendapatkan kepercayaan untuk menjadi lokasi gathering sebuah komunitas otomotif yaitu Taft Diesel Indonesia (TDI). Selain menggelar kegiatan gathering, komunitas 
TDI tersebut juga melakukan bakti sosial untuk warga Dusun Grogol VII yang kurang mampu serta memberikan bantuan kepada pokja berupa bahan bangunan untuk mendirikan mushola serta sejumlah uang sebesar Rp5.000.000,00 untuk pengembangan kamar mandi. Dana bantuan sebesar Rp5.000.000,00 yang diberikan oleh komunitas TDI kemudian diwujudkan oleh pokja menjadi 22 unit kamar mandi sehingga total kamar mandi di Pantai Cemara Sewu ada 26. Bantuan yang diberikan oleh komunitas TDI tersebut membuat fasilitas wisata di Pantai Cemara Sewu semakin lengkap.

\subsubsection{Warung Makan}

Untuk memenuhi permintaan pengunjung yang menginginkan makanan dan minuman saat mereka berwisata, maka diawal tahun 2017 pokja memutuskan untuk membangun warung makan (periksa gambar 2). Proses pembangunan warung makan yang dikerjakan selama kurang lebih 2 minggu tersebut berjalan lancar, namun kendala justru muncul ketika warung telah selesai dibangun. Pada waktu itu, pengurus tidak bisa membeli barang dagangan untuk mengisi warung makan karena dana kas yang dimiliki telah tersedot untuk pembangunan warung serta aula di mana kedua fasilitas tersebut dikerjakan dalam waktu yang bersamaan. Sudarman kemudian mensiasati kondisi tersebut dengan inisiatif membawa barang dagangan yang ada di warung miliknya untuk dijual di warung Pantai Cemara Sewu. Tindakan Sudarman tersebut murni ia lakukan secara suka rela, dan ia pun menyarankan agar keuntungan dari penjualan warung untuk masuk menjadi kas kelompok supaya kas kelompok dapat terisi kembali.

Pada awal perkembangan warung makan, pengurus dihadapkan dengan sebuah tantangan yaitu mengajak ibu-ibu warga Dusun Grogol VII untuk terlibat dalam pengelolaan warung. Ajakan tersebut tidak direspon positif oleh ibu-ibu sebab mereka merasa pesimis akan keberlangsungan Pantai Cemara. ${ }^{2}$ Oleh karena itu, jumlah ibu-ibu yang berhasil direkrut pada waktu itu hanya ada 3 orang. Berangsur Pantai Cemara Sewu ramai dikunjungi wisatawan merubah pandangan ibu-ibu yang semula pesimis kini menjadi antusias untuk ikut terlibat. Dari yang semula hanya ada 3 orang kini bertambah menjadi 12 orang. Untuk memudahkan pengelolaanya, 12 orang tersebut dibagi menjadi
3 kelompok yang akan bekerja secara bergiliran sesuai dengan jadwal yang telah dibuat. Selain warung makan, pokja juga menyediakan lahan kosong yang dapat dipergunakan oleh anggota yang ingin membuka usaha mandiri di Pantai Cemara Sewu. Ada 20 orang yang membuka lapak dengan berbagai jenis dagangan seperti menjual sosis bakar, rujak buah, es dawet dan juga aksesoris seperti kacamata, topi dan pakaian. Sebagian besar pedagang hanya membuka lapaknya saat akhir pekan atau hari libur. Hal ini dikarenakan rendahnya tingkat kunjungan pada hari biasa atau hari Senin hingga Jumat, sehingga mereka lebih memilih untuk mengerjakan pekerjaan lain di luar Pantai Cemara Sewu.

\section{Gambar 2. Warung Makan}

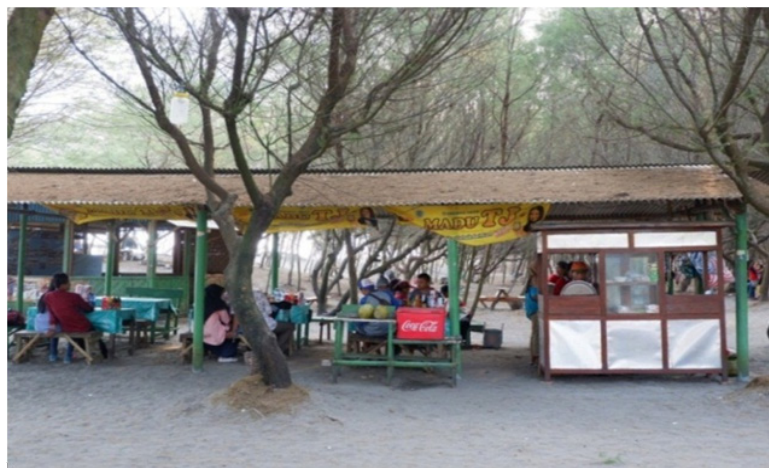

(Sumber: Sari, 2017)

Ketika warung makan sudah berjalan sekitar 6 bulan, pengurus merasa ada kejanggalan yang terjadi pada pembukuan hasil penjualan warung. Pengurus mendapati jumlah uang yang terkumpul tidak sesuai dengan angka yang tertulis pada pembukuan, dan sulit untuk mengencek karena pendapatan warung makan telah digabung menjadi satu dengan pendapatan parkir. Setelah dievaluasi pada rapat bulanan yang dilaksanakan setiap tanggal 17 ternyata letak kesahalahannya ada dicara penghitungan di mana modal belanja selalu ikut dihitung sehingga terkesan mendapatkan uang yang banyak. Belajar dari kesalahan tersebut, pengurus kemudian memberitahu ibu-ibu tentang cara pembukuan yang benar dengan cara menerapkan harga dasar dan harga jual. Harga dasar merupakan estimasi dari total biaya yang dikeluarkan untuk membuat suatu produk, sedangkan harga jual adalah 
nominal harga yang diberikan kepada pembeli. Selain itu, pengurus juga memisahkan pembukuan antara warung dan parkir supaya lebih mudah untuk dicek. Keuntungan yang didapat warung makan tidak langsung dibagikan ke ibu-ibu yang bekerja melainkan disisihkan terlebih dahulu sebesar $40 \%$ untuk masuk kas dan $60 \%$ digabungkan dengan pendapatan parkir baru kemudian dibagikan kepada anggota yang bekerja. Pengurus menggabungkan pendapatan warung makan dengan pendapatan parkir dengan tujuan supaya semua anggota memperoleh hasil yang merata.

Setelah masalah pembukuan teratasi muncul gejolak lain yaitu bersumber dari aturan yang dibuat oleh pengurus bahwasanya setiap anggota yang membuka lapak harus berjualan produk yang berbeda dengan produk yang dijual oleh warung makan. Aturan tersebut ditaati oleh semua anggota yang membuka usaha, namun berjalannya waktu justru keadaannya terbalik di mana warung makan menjual barang dagangan yang sama dengan yang dijual oleh anggota. Peristiwa tersebut dialami oleh Mbak Yuli salah satu anggota yang membuka usaha di Pantai Cemara Sewu. Menurut Mbak Yuli dirinya lah yang pertama kali menjual minuman pop ice namun kemudian warung makan juga mengikut menjual pop ice. Kekecewaan tersebut ia sampaikan kepada pengurus dan oleh pengurus aturan tersebut akhirnya dihapus sehingga sekarang setiap anggota bebas berjualan produk apapun.

\subsubsection{Mushola}

Berbeda dengan fasilitas-fasilitas sebelumnya yang dibangun swadaya oleh pokja, mushola ini merupakan fasilitas yang dibangun berkat adanya bantuan dari komunitas Taft Diesel Indonesia (TDI) yang berkunjung ke Pantai Cemara Sewu pada tanggal 22 April 2017. Komunitas TDI memberikan bantuan dana kepada pengurus pokja sebesar Rp5.000.000,00 untuk pengembangan kamar mandi dan material bangunan untuk mendirikan mushola yang pengerjaanya diserahkan kepada pokja. Dengan menyesuaikan ketersediaan bahan bangunan yang diberikan oleh komunitas TDI, pokja membangun mushola dengan luas 4x6 $\mathrm{m}$ yang dapat menampung sekitar 8 orang. Satu tahun setelahnya, pokja merencanakan untuk merenovasi mushola supaya lebih besar sehingga pengunjung yang ingin menunaikan ibadah tidak perlu lagi mengantri.
Masih dalam proses diskusi mengenai rencana merenovasi mushola, tidak disangka ada bantuan datang dari salah satu anggota TDI berupa uang sebesar Rp100.000.000,00 yang juga kebetulan diamanahkan untuk merenovasi mushola. Dana yang cukup besar tersebut kemudian disalurkan oleh pengurus untuk membeli pendopo joglo yang nantinya akan digunakan sebagai mushola. Mushola yang diberi nama oleh pengurus yaitu Ar-Rahma memiiliki luas 9x11 m yang dapat menampung sekitar 100 orang (periksa gambar 3).

\section{Gambar 3. Mushola Ar-Rahma}

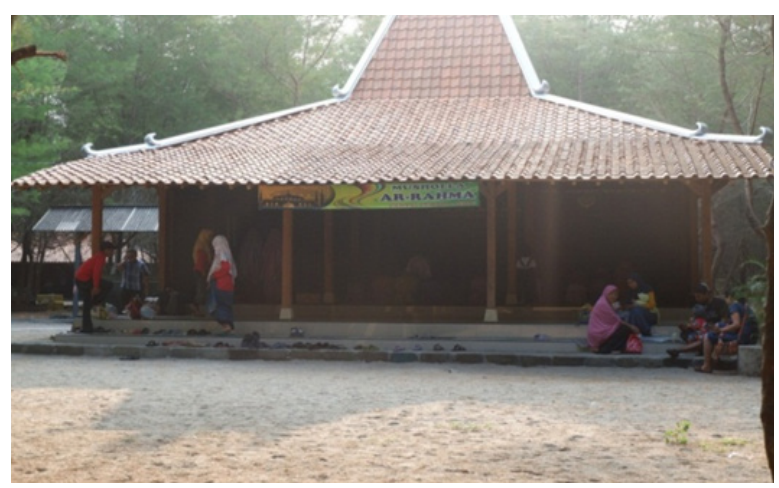

(Sumber: Sari, 2017)

Selanjutnya bangunan mushola yang lama dimanfatakan oleh pokja untuk disulap menjadi kantor sekretariat guna memudahkan untuk pemberian informasi kepada pengunjung yang akan mengadakan kegiatan di Pantai Cemara Sewu. Pokja sepakat agar penyampaian informasi tentang wisata di Pantai Cemara Sewu dikelola oleh pengurus. Pengelolaan informasi yang terpusat pada satu pintu diharapkan dapat meminimalisir kesalahan ataupun perbedaan informasi mengenai Pantai Cemara Sewu.

\subsubsection{Aula}

Pengunjung yang datang ke Pantai Cemara Sewu memiliki tujuan yang bermacam-macam. Ada pengunjung yang datang hanya untuk menikmati pantai, namun juga tidak sedikit pengunjung yang datang dengan tujuan tertentu misalnya mengadakan acara arisan ataupun gathering. Untuk mengakomodir kebutuhan tersebut, pokja kemudian memutuskan untuk membangun aula. Pembangunan aula dilaksanakan oleh pokja pada awal tahun 2017. 
Aula tersebut dibangun menggunakan bambu sebagai fondasinya dengan kapasitas yang dapat menampung sekitar 50 orang. Oleh pengurus aula tersebut kemudian disewakan dengan tarif Rp100.000,00 per 6 jam. Berjalan 6 bulan, pokja mulai merencanakan untuk membangun aula lagi. Selama proses diskusi tersebut, terjadi perdebatan karena ada 2 kubu di mana yang satu menginginkan untuk ditambah 2 unit aula sedangkan yang satunya lagi cukup hanya dengan menambah 1 unit aula. Kubu yang ingin manambah 2 unit aula berfikiran bahwa dengan ditambahnya 2 unit aula akan cukup mengakomodir kebutuhan pengunjung yang ingin menggelar acara di Pantai Cemara Sewu, sementara kubu lain menganggap bahwa penambahan 2 unit aula tersebut adalah kegiatan yang menghamburhamburkan biaya. Setelah melalui musyawarah, maka diambil suara terbanyak yaitu menambah 2 unit aula. ${ }^{3}$

Dua unit aula dibangun satu di bagian barat dan satu lagi bagian timur Pantai Cemara Sewu. Aula tersebut berbentuk pendopo joglo yang dapat menampung sekitar 75 sampai dengan 100 orang. Mengingat bahwa daya tampung aula pendopo joglo lebih banyak, maka pengurus memutuskan untuk memberikan harga sewa yang lebih tinggi yaitu sebesar Rp50.000,00 per jamnya. Pengembangan aula tersebut juga tidak terlepas dari permasalahan internal yang terjadi di antara pengurus dengan anggota. Masalah tersebut terjadi lantaran pengurus memutuskan untuk tidak membagikan pendapatan yang diperoleh dari 2 aula pendopo joglo kepada anggota melainkan disimpan terlebih dahulu. Keputusan yang diambil oleh pengurus bukan tanpa alasan karena mengingat pembangunan 2 pendopo joglo tersebut menelan biaya yang cukup besar, yaitu Rp75.000.000,00 sehingga mereka ingin mengetahui berapa lama modal tersebut dapat kembali. Maksud baik pengurus tersebut tidak dipahami oleh Sudarman, ia menilai bahwa keputusan tersebut dapat merugikan anggota Pokja. Untuk menanggulangi kesalahpahaman tersebut pengurus kemudian membuatkan pembukan khusus untuk aula pendopo yang akan rutin dilaporkan dalam setiap rapat kelompok. Hal tersebut dilakukan agar terjalin keterbukaan antara pengurus dengan anggota.

\subsection{Sistem Pendanaan Untuk Pengembangan Fasilitas di Pantai Cemara Sewu}

Seluruh fasilitas wisata yang ada di Pantai Cemara Sewu dibangun oleh Pokja secara mandiri dan swadaya. Pokja tidak pernah meminta bantuan dana kepada pihak manapun baik pemerintah maupun swasta untuk mengembangkan fasilitas wisata di Pantai Cemara Sewu karena Pokja merasa mampu dan lebih puas jika pengembangan pariwisata merupakan hasil kerja keras mereka sendiri. Alasan utama yang membuat Pokja memilih untuk bergerak secara mandiri tidak menggandeng pemerintah dalam pembangunan fasilitas adalah penilaian mereka yang negatif terhadap sistem dan kinerja pemerintah yang dianggap mencari keuntungan setelah mengetahui adanya potensi wisata yang berkembang. Tidak hanya dengan pemerintah, Pokja juga sangat berhati-hati dalam menerima tawaran bantuan dari pihak swasta. Pokja memiliki kriteria khusus untuk menerima bantuan dari pihak luar yaitu pihak tersebut harus benar-benar memiliki niat ikhlas dan tulus memberikan bantuan semata-mata untuk kemajauan Pantai Cemara Sewu tanpa maksud mengambil keuntungan setelahnya. Sikap Pokja yang tegas terhadap pihak luar baik itu dengan pemerintah maupun swasta tidak lepas dari kesadaran mereka bahwa pengembangan pariwisata di Pantai Cemara Sewu tersebut sejak awal dibangun hingga seperti sekarang yaitu berkat usaha kerja keras dari masyarakat sendiri.

Pada awal tahun 2017 Pokja membuka pendaftaran bagi warga Dusun Grogol VII yang mau bergabung menjadi anggota Pokja. Biaya yang dikenakan untuk menjadi anggota Pokja ialah sebesar Rp4.000.000,00 bagi mereka yang mampu, sedangkan bagi yang kurang mampu akan diberikan keringan dengan cukup membayar setengah yaitu sebesar Rp2.000.000,00. Uang pendaftaran tersebut kemudian digunakan oleh Pokja untuk membiayai pembangunan fasilitas wisata di Pantai Cemara Sewu. Selain mengandalkan uang pendaftaran dari warga yang ingin menjadi anggota Pokja, hasil pemasukan dari fasilitas-fasilitas juga turut digunakan untuk membiayai pengembangan fasilitas wisata di Pantai Cemara Sewu. Telah disepakati bahwa seluruh pemasukan dari fasilitas akan disisihkan sebesar $40 \%$ untuk masuk kas sedangkan sisanya $60 \%$ dibagikan kepada anggotaanggota yang bekerja. Uang kas inilah yang 
kemudian digunakan untuk pengembangan fasilitas di Pantai Cemara Sewu.

\subsection{Kondisi Perekonomian Masyarakat Dusun Grogol VII Setelah Terlibat DalamPengembangan Fasilitas di Pantai Cemara Sewu}

Masyarakat Dusun Grogol VII yang tergabung dalam Pokja Pantai Cemara Sewu terlibat aktif dalam penyediaan fasilitas di Pantai Cemara Sewu karena dari sinilah keuntungan didapat oleh masyarakat dari kegiatan pariwisata. Setiap anggota Pokja bebas untuk memilih profesi atau kegiatan yang akan mereka lakukan di Pantai Cemara Sewu seperti menjadi juru parkir, penjaga kamar mandi, pelayan di warung makan kelompok, atau membuka usaha mandiri seperti berdagang.

\subsubsection{Tambahan Penghasilan dari Penyediaan Fasilitas}

Pengurus merasakan bahwa pencapaian yang dimiliki Pantai Cemara Sewu saat ini merupakan sesuatu yang layak untuk disyukuri. Hal ini terkait dengan manfaat yang dirasakan oleh semua anggota Pokja dengan adanya tambahan penghasilan yang sedikit banyak dapat membantu mengatasi kesulitan ekonomi mereka. Dari total jumlah anggota Pokja Pantai Cemara Sewu sebanyak 71 orang, ada sebanyak 54 orang yang terlibat menjadi petugas harian pada fasilitas-fasilitas yang telah mereka bangun yaitu seperti menjadi juru parkir, penjaga kamar mandi, serta pelayan warung makan. Sedangkan sisanya sebanyak 17 orang memilih untuk membuka usaha pribadi yaitu berdagang. Dari keterlibatannya menjadi petugas harian pada fasilitas anggota yang bekerja memperoleh penghasilan. Upah atau penghasilan yang didapatkan oleh anggota dengan menjadi petugas harian tergantung pada jumlah kehadiran pengunjung di Pantai Cemara Sewu, sehingga penghasilan mereka setiap harinya tidak selalu sama.

Ketika hari biasa (Senin-Sabtu) rata-rata omzet yang didapat oleh pengurus dari penyediaan fasilitas wisata yaitu berkisar antara Rp400.000,00 sampai dengan Rp600.000,00. Sebelum dibagikan ke anggota, pendapatan tersebut disisihkan terlebih dahulu sebesar $40 \%$ untuk masuk kas dan sisanya $60 \%$ dibagikan kepada anggota yang bekerja pada hari itu. Dalam satu hari di hari biasa anggota yang bekerja menjadi petugas harian memperoleh penghasilan berkisar Rp50.000,00 sampai dengan Rp60.000,00. Kondisi demikian akan berbeda ketika hari Minggu ataupun hari libur. Ketika hari Minggu, Pantai Cemara Sewu lebih ramai ketimbang hari biasa sehingga pendapatan yang diperoleh pun juga melonjak yang berarti penghasilan yang didapat anggota juga turut meningkat. Rata-rata omzet yang didapat pengurus pada hari Minggu yaitu berkisar antara Rp5.000.000,00 sampai dengan Rp6.000.000 dan perolehan yang didapat anggota berkisar antara Rp100.000,00 sampai dengan Rp120.000,00.

Bagi sebagian besar anggota yang bekerja menjadi petugas harian merasakan bahwa penghasilan yang diperoleh lumayan, dalam arti hasil yang diperolehnya dapat dijadikan sebagai tambahan penghasilan selain dari pekerjaan utama. Sebagaimana yang dialami oleh Bapak Slamet yang sehari-harinya bekerja menjadi buruh tani. Dari pekerjaanya menjadi buruh tani Bapak Slamet mendapatkan upah sebesar Rp60.000,00 setiap harinya. Pekerjaannya menjadi buruh tani tidak membutuhkan waktu seharian penuh hanya bekerja di pagi hari dan sore hari sedangkan siang harinya dia menganggur. Dengan menjadi anggota Pokja Pantai Cemara Sewu dan ikut terlibat dalam penyediaan fasilitas Bapak Slamet kini dapat mengisi waktu siangnya dengan bekerja menjadi petugas harian di Pantai Cemara Sewu. Penghasilan yang ia dapatkan dari bekerja menjadi petugas harian di Pantai Cemara dapat menjadi pendapatan tambahan.

\subsubsection{Usaha Dagang}

Selain membuka peluang kerja, pengurus juga menyediakan lahan kosong yang dapat dimanfaatkan oleh anggota untuk membuka usaha. Salah satu anggota yang memanfaatkan kesempatan tersebut ialah Mbak Yuli. Ketika hari Senin hingga Sabtu Mbak Yuli bekerja menyewakan payung di Pantai Parangtritis, dan pada hari Minggu Mbak Yuli berjualan rujak buah, dan pop ice di Pantai Cemara Sewu. Untuk satu porsi rujak buah Mbak Yuli menjual dengan harga Rp10.000,00, dan satu gelas pop ice dijual dengan harga Rp5.000,00. Dalam satu hari Minggu Mbak Yuli bisa meraup keuntungan bersih dari berjualan pop ice dan rujak buah berkisar Rp.100.000,00-200.000,00. 
Dari keuntungannya berjualan di Pantai Cemara Sewu, Mbak Yuli bisa memperkerjakan orang untuk menjaga payung di Pantai Parangtritis saat hari Minggu.

Selain bisa memperoleh tambahan penghasilan, seluruh anggota baik yang memilih untuk menjadi petugas harian maupun berdagang akan mendapatkan pembagian sisa hasil usaha (SHU). SHU yang diterima oleh masing-masing anggota akan berbeda tergantung dengan uang masuk yang dahulu dibayarkan ketika mendaftar menjadi anggota Pokja Pantai Cemara Sewu. Oleh karena ada 2 kategori biaya masuk, maka berdasarkan kesepakatan yang telah dibuat bersama yaitu bagi kategori satu akan memperoleh SHU penuh, sedangkan untuk kategori dua akan memperoleh SHU sebesar 50\% atau hanya setengah dari SHU penuh. Rencana mengenai pembagian SHU ini sudah dibahas oleh pengurus sejak tahun 2017, namun hingga tahun 2018 rencana pembagian SHU tersebut belum bisa terwujud. Belum dapat terealisasikannya pembagian SHU karena pengurus masih menimbang berapa persen SHU yang harus disisihkan untuk menjadi kas dan berapa persen SHU yang dibagikan ke anggota. Oleh karena masing-masing pengurus memiliki keinginan dan pemikiran yang berbeda-beda mengenai sistem pembagian SHU, sehingga perlu waktu untuk menyatukan berbagai pemikiran mereka supaya dapat memperoleh hasil yang mufakat.

\section{Kesimpulan}

Pantai Cemara Sewu adalah objek wisata pantai yang dibangun dan dikelola secara mandiri oleh masyarakat Dusun Grogol VII. Pengembangan pariwisata Pantai Cemara Sewu mulai dilakukan pada tahun 2016 diawali dengan membangun fasilitas wisata. Keterlibatan masyarakat dalam penyediaan fasilitas di Pantai Cemara Sewu secara garis besar terbagi menjadi dua, yakni pembangunan fasilitas dan pengelolaan fasilitas. Pada saat pembangunan fasilitas masyarakat terlibat aktif bertindak sebagai subjek pembangunan dengan terlibat dalam bentuk pikiran, tenaga, bahkan materi seperti uang. Fasilitas wisata yang pertama dibangun oleh masyarakat ialah tempat parkir dan kamar mandi karena menurut masyarakat kedua fasilitas tersebut memiliki peranan penting dan harus ada di sebuah tempat wisata. Kemudian mengikuti kebutuhan pengunjung masyarakat membangun warung makan, musola, serta aula pertemuan. Selanjutnya dalam pengelolaan fasilitas masyarakat membuat kesepakatan mengenai sistem pembagian pendapatan dari penyediaan fasilitas yang dibagi dalam bentuk persen yaitu dari jumlah keseluruhan akan dibagi sebesar $40 \%$ untuk kas dan sisanya $60 \%$ menjadi bagian anggota. Penyediaan fasilitas yang dilakukan oleh masyarakat Dusun Grogol VII di Pantai Cemara Sewu telah memberikan mereka alternatif pekerjaan lain serta kesempatan usaha. Pendapatan yang masyarakat peroleh dari hasil berjualan maupun upah dari bekerja menjadi petugas parkir, penjaga kamar mandi ataupun pelayan di warung makan dapat memberikan mereka tambahan penghasilan selain dari pekerjaan utama mereka.

Dalam prosesnya, pengembangan fasilitas wisata di Pantai Cemara Sewu tidak jarang menemui berbagai masalah dan kendala. Secara garis besar, masalah dan kendala tersebut muncul akibat adanya perbedaan pandangan di antara pengurus dan anggota terkait dengan pengembangan fasilitas wisata. Permasalahan dan kendala tersebut tidak menyurutkan semangat masyarakat untuk melanjutkan pengembangan fasilitas wisata tetapi justru mendorong masyarakat untuk semakin kreatif dan pada akhirnya dijadikan oleh masyarakat sebagai media belajar mengenai pengelolaan wisata. Pada penelitian ini juga ditemukan bahwa terdapat peran aktor yang sangat kuat dalam menggerakkan masyarakat untuk terlibat dalam pengembangan fasilitas. Aktor tersebut ialah Sudarman di mana beliau adalah penggagas berdirinya Pantai Cemara Sewu serta yang menggerakkan masyarakat untuk ikut terlibat dalam pengembangan fasilitas. Kedepannya akan ada kemungkinan aktor baru yang muncul dalam proses pengembangan wisata di Pantai Cemara Sewu. Oleh sebab itu, diperlukan penelitian-penelitian lanjutan mengenai pergantian aktor dalam pengembangan pariwisata khususnya yang melibatkan masyarakat desa. Di samping itu, penelitian ini hanya fokus pada tambahan penghasilan belum mencangkup mengenai kesejahteraan masyarakat yang terkait dengan kemampuan mencukupi kebutuhan biaya hidup seperti pendidikan, kesehatan, dan tempat tinggal. Oleh sebab itu diperlukan penelitian lanjutan untuk 
menghitung apakah keterlibatan masyarakat dalam pengembangan fasilitas wisata berkorelasi pada peningkatan kesejahteraan masyarakat.

\section{Catatan Akhir}

1) Hasil wawancara dengan Sudarman selaku penggagas berdirinya Pantai Cemara Sewu pada tanggal 27 Januari 2018.

2) Hasil wawancara dengan Sugiran selaku ketua pengurus kelompok Pantai Cemara Sewu pada tanggal 5 Februari 2018.

3) Hasil wawancara dengan Yana selaku seksi keuangan dalam kepengurusan kelompok Pantai Cemara Sewu pada tanggal 5 Februari 2018.

\section{Daftar Pustaka}

Ahimsa-Putra, Heddy Shri. (2003). Ekonomi Moral, Rasional, dan Politik. Yogyakarta: Kepel Press.

Ahimsa-Putra, Heddy Shri. (2011). Pariwisata di Desa dan Respon Ekonomi: Kasus Dusun Brayut di Sleman, Yogyakarta. Jurnal Patrawidya Vol. 12, No. 4: 635-657.

Aref, Fariborz., Sarjit S Gill., Farshid Aref. (2010). Tourism Development in Local Communities: As a Community Development Approach. Journal of American Science, 6(2): 155-161.
Damanik, J. 2013. Pariwisata Indonesia: Antara Peluang dan Tantangan. Yogyakarta: Pustaka Pelajar.

Hudayana, Bambang. (2018). Pendekatan Antropologi Ekonomi. Yogyakarta: Kepel Press.

Purwahandoyo, Joni., Esti Cemporaningsing., Punto Wijayanto. (2016). Pariwisata Kota Pusaka Mendayagunakan Aset Pusaka, Menyejahterakan Masyarakat. Yogyakarta: Gadjah Mada University Press.

Raharjana, Destha Titi. (2012). Membangun Pariwisata Bersama Rakyat: Kajian Partisipasi Lokal Dalam Membangun Desa Wisata Dieng Plateu. Kawistara, 2, 3, 225-328.

Spillane, J.J. (1994). Pariwisata Indonesia Siasat Ekonomi dan Rekayasa Kebudayaan. Kanisius: Yogyakarta.

Sugiyono. (2012). Metode Penelitian Kuantitatif, Kualitatif, dan R\&D. Bandung: Alfabeta.

\section{Wawancara}

Wawancara Sudarman, Dusun Grogol VII, Bantul, Yogyakarta, 22 Juni 2017, pukul 14.45-17.00 WIB

Wawancara Yana, Dusun Grogol VII, Bantul, Yogyakarta, 5 Februari 2018, pukul 19.05-21.10 WIB

Wawancara Sugiran, Dusun Grogol VII, Bantul, Yogyakarta, 5 Februari 2018, pukul 19.05-21.10 WIB 